\title{
Otis II: light at the end of the tunnel for damages indirectly caused by competition law infringements
}

\author{
Sílvia Bessa Venda \\ Universidade Católica Portuguesa - Porto (PhD Cand.)
}

The Background

Improving the private enforcement of competition law is one of the EU goals. Indeed, Regulation 1/2003' confers competence to apply Articles 101 and 102 TFEU (which prohibit anticompetitive agreements and abuses of dominant position, respectively), in addition to the European Commission and national competition authorities, to national courts. Only the combination between public and private enforcements makes it possible to guarantee full compliance with these antitrust rules, which generate rights and obligations both for Member-states (MS) and individuals. They also have direct effect, i.e., they can be invoked directly by individuals in national contexts, either against the State (direct vertical effect) or against other individuals (direct horizontal effect). Thus, the effective application of Articles 101 and 102 TFEU presupposes not only the prevention and punishment of their infringement, but also the protection and compensation of the damages caused by that infringement to undertakings and consumers.

\footnotetext{
${ }^{1}$ Council Regulation (EC) 1/2003, of 16 December 2002, on the implementation of the rules on competition laid down in Articles 81 and 82 of the Treaty.
} 
ULP Law Review | Revista de Direito da ULP

Vol. 13, n. .9

doi:10.46294/ulplr13nlv1

The individuals' right (including public authorities) to seek compensation for the harm caused to them by an infringement of Articles 101 and 102 TFEU, i.e., to effective judicial ${ }^{2}$ protection, was recognized for the first time, by the ECI, in the Courage ruling ${ }^{3}$. However, before the Private Enforcement Directive ${ }^{4}$, EU law did not regulate this specific type of damages actions. Five years later, in the Manfredi ${ }^{5}$ ruling, the ECJ ruled that, in the absence of EU rules, it was for the domestic legal system of each MS to prescribe the detailed rules governing the exercise of that right, including those on the application of the concept of "causal relationship". The need for such a link, between the infringement of competition law and the harm suffered, to seek compensation was subsequently confirmed by an ECJ ruling also called Otis', in 2012.

After almost a decade of deliberation, the Directive referred above was finally adopted, on 26 November 2014, with the purpose of ensuring an effective protection for anyone who has suffered harm caused by an infringement of the competition law ${ }^{8}$. It provides that, in compliance with the principles of effectiveness and equivalence, national rules and procedures relating to the exercise of claims for damages should (i) not render practically impossible or excessively difficult the exercise of the EU right to compensation and (ii) not be less favourable to the alleged injured parties than those governing similar actions for damages resulting from infringements of national law? ${ }^{9}$. Among the several rules laid down in the Directive, it should also be stressed that, according to it, compensation of harm can be claimed by anyone who suffered it, irrespective of whether they are direct or indirect purchasers from an infringer ${ }^{10}$. In addition, it provides the rebuttable presumption (reversal

\footnotetext{
${ }^{2}$ See ROBERTO CISOTTA, Some Considerations on the Last Developments on Antitrust Damages Actions and Collective Redress in the European Union, (The Competition Law Review 10, 2014), 88.

${ }^{3}$ Of 20 September 2001, C-453/99. See SOFIA OLIVEIRA PAIS and ANNA PISZCZ, Package on Actions for Damages Based on Breaches of EU Competition Rules: Can One Size Fit All?, (Yearbook of Antitrust and Regulatory Studies 7, no. 10, 2014), 211.

${ }^{4}$ Directive 2014/104/EU of the European Parliament and the Council, of 26 November 2014, on certain rules governing actions for damages under national law for infringements of the competition law provisions of the Member States and of the European Union.

${ }^{5}$ of 13 July 2006, C-295/04 to C-298/04.

${ }^{6}$ See paragraph 64.

${ }^{7}$ of 6 November 2012, Case C-199/11.

${ }^{8}$ See Recital 4 and Article 1(1).

${ }^{9}$ See Article 4.

${ }^{10}$ See Article 12.
} 
ULP Law Review | Revista de Direito da ULP

Vol. 13, n. $\stackrel{1}{ }$

doi:10.46294/ulplr13nlv1

of the burden of proof) that cartels cause harm ${ }^{11}$. However, the Directive does not provide for anything regarding the causal link other than the following reference in the recitals: national rules (...) including those concerning aspects not dealt with in this Directive such as the notion of causal relationship between the infringement and the harm, must observe the principles of effectiveness and equivalence ${ }^{12}$.

Between 2006 and 2018, the ECI issued about six rulings deepening some of the above issues but, only in 2019, issued three important decisions on the private enforcement of competition law: $S k a n s k a^{13}$, $\operatorname{Cogeco}^{14}$ and, more recently, Otis. Very briefly and before we go deeper into the last one, Skanska is a game changer in terms of liability for damage caused by infringements of competition law. According to the EC, successor undertakings ${ }^{15}$ assume the liability as they have, as legal persons, ensured that [the undertakings participating in the carter meanwhile dissolved] were able to continue their economic activities $^{16}$. Cogeco, on the other hand, deals with the temporal scope of the Private Enforcement Directive ${ }^{17}$ and the compatibility of the time limit for bringing actions for damages as provided for in the Portuguese Civil Code ${ }^{18}$ with EU competition law and the principles of equivalence and effectiveness. For the ECI, a national legislation which, first, provides that the limitation period in respect of actions for damages is three years and starts to run from the date on which the injured party was aware of its right to compensation, even if unaware of the identity of the person liable and, secondly, does not include any possibility of suspending or interrupting that period during proceedings before the national competition authority ${ }^{19}$ is contrary to the EU law.

\footnotetext{
"See Article 17(2).

${ }^{12}$ See Recital 11.

${ }^{13}$ of 14 March 2019, (-724/17.

${ }^{14}$ Of 28 March 2019, C-637/17.

${ }^{15}$ See Chantal LAVOIE, Court of Justice Ruling in Skanska: EU Competition Law Concept of 'Undertakings' and Principle of Economic Continuity to the Rescue in Civil Damages Claims, 2019, in hitp://competitionlawblog.kluwercompetitionlaw.com/2019/03/22/court-of-justice-ruling-in-skanska-eucompetition-law-concept-of-undertakings-and-principle-of-economic-continuity-to-the-rescue-in-civildamages-claims/.

${ }^{16}$ See paragraph 50.

${ }^{17}$ See CATARINA VIEIRA PERES, The Cogeco Case: The First Preliminary Ruling on the Private Enforcement Directive, (Market and Competition Law Review 3, no. 2, October 1, 2019), 81-106.

${ }^{18}$ Article 498(1).

${ }^{19}$ See paragraph 55.
} 
ULP Law Review | Revista de Direito da ULP

Vol. 13, n. .9

doi:10.46294/ulplr13nlv1

\section{The facts and the opinion of the Advocate General}

This ruling responds to a request for a preliminary ruling from the Oberster Gerichtshof (Austrian Supreme Court), in the context of a damage action presented inter alia by the Land Oberösterreich (the applicant) against five undertakings condemned for participating in a cartel on the market for the installation and maintenance of lifts and escalators. The cartel objective was securing for the favoured undertaking a higher price.

The applicant did not claim as a direct or indirect customer of the products covered by the cartel but as a body granting subsidies. According to it, the increased costs connected with the installation of lifts, included in the overall costs, caused by the cartel led it to grant subsidies, in the form of promotional loans for the purpose of financing construction projects, in higher amounts than would have been the case in the absence of that cartel, depriving the applicant of the possibility to invested differently. On the other hand, the infringing undertakings and the Austrian courts of the first and last instance held that, according to the Austrian law, the damages suffered by the applicant did not present a sufficient connection with the purpose of the prohibition of anticompetitive agreements, which is to protected competition on the market affected by the cartel at issue. Accordingly, the Austrian Supreme Court questioned the $\mathrm{ECJ}$ whether those who are not active, as suppliers or customers, on the market affected by the anticompetitive agreement, can claim compensation for the damages they have indirectly suffered.

The Advocate General (AG) Juliane Kokott starts by focusing the question as a problem of causality: is there a sufficiently direct causal link or is it a very remote injury whose compensation cannot reasonably be imposed on the cartel participants ${ }^{20}$ ?

She points out that, notwithstanding the above-mentioned recital of the Private Enforcement Directive, as regards the application of the concept of causation be for the national legal systems (provided that the principles of equivalence and effectiveness are

${ }^{20}$ See paragraph 47. 
ULP Law Review | Revista de Direito da ULP

Vol. 13, n. .9

doi:10.46294/ulplr13n lv1

respected), the issue at stake here is one aspect of the examination of causality which does not concern the modalities of application but rather the material assumptions of the right to compensation for damage caused by infringements of competition law. For the $A G$, the real question is whether Arricle 101 TFEU also confers on an undertaking (in this case, a public lender) who did not operate as a supplier or as a buyer on the market affected by the cartel the right to compensation for the damage it has suffered as a result of the cartel. That's why, for the $A G$, this is a matter of EU law (interpretation of the Treaties) ${ }^{21}$.

As to whether there is a sufficiently direct causal link between the elevator cartel and the damage for which the complainant seeks compensation, the $A G$ concluded that the relationship between the inflated price of the installed lifts and the percentage amount of each loan calculated to purchase them can be proven in each individual case. According to the $A G$, this case illustrates the diversity of damage which can be caused by anticompetitive behaviors and which is not limited to damage caused directly or indirectly to suppliers or buyers in a market affected by a cartel or an adjacent market, nor to damage occurring in the course of engaging in a profitable activity ${ }^{22}$.

\section{The ECJ ruling}

The ECJ began by recalling the above-mentioned case law, in particular as regards the direct effects of Article 101 TFEU on the legal sphere of individuals. It reaffirmed that its full effectiveness implies that any person may claim compensation for damage caused to it as a result of an infringement of competition rules ${ }^{23}$.

In substance, the ECJ agreed with the AG in the sense that if the capability to claim for compensation were limited to suppliers and customers of the market affected by the cartel, this right would be compromised ${ }^{24}$. According to this ruling, any loss which has a causal

\footnotetext{
${ }^{21}$ See paragraph 52.

${ }^{22}$ See paragraph 79.

${ }^{23}$ See paragraphs 21 and 22.

${ }^{24}$ See paragraph 27.
} 
ULP Law Review | Revista de Direito da ULP

Vol. 13, n. .9

doi:10.46294/ulplr13n lv1

connection with an infringement of Article 101 TFEU must be capable of giving rise to compensation in order to ensure the effective application of Arricle 101 TFEU and to guarantee the effectiveness of that provision ${ }^{25}$.

Finally, the EIJ decided, in abstract, that even who is not acting as supplier or customer on the market affected by the cartel must be able to claim compensation for damage resulting from it, namely, whether it was obliged to grant subsidies which were higher than if that cartel had not existed and, consequently, was unable to use that difference more profitably. However, it is for the national court to determine the existence of such damage and its relationship with the cartel $^{26}$.

\section{Conclusive remarks}

Otis has come to clarify that "who" and "where" do not matter provided that there is a causal link between the damage and the competition law infringement. The members of a cartel, for instance, are responsible for compensating for all the damages they cause ${ }^{27}$, irrespective of in whom and on which market they manifest themselves. In short, anyone has the right to be compensated.

Furthermore, it points out that the assumptions of liability for breaches of $\mathrm{EU}$ competition rules are a matter of $\mathrm{EU}$ law $^{28}$ and, as such, it is for the $\mathrm{EJJ}$ to examine, in a general perspective, whether they are fulfilled. On the other hand, judge if these conditions are satisfied in the specific case it for the national courts ${ }^{29}$.

\footnotetext{
${ }^{25}$ See paragraph 30.

${ }^{26}$ See paragraphs 32 and 33.

${ }^{27}$ ALBERT KNIGGE and RICK CORNELISSEN, The Judgment of the CJEU in Otis and Others (C-435/18): Indirect Losses May Need to Be Compensated, (Lexology, 2020), in https://www.lexology.com/library/detail.aspx?g = bb549a7b-d0da-4bb6-9a91-37a5ca375637.

${ }^{28}$ See MIGUEL SOUSA FERRO and GUILHERME OLIVEIRA E COSTA, Otis: Another Great Judgment on Private Enforcement from the CJEU... But It Could Be Better, (Competition Policy International, January 22, 2020), in https://www.competitionpolicyinternational.com/otis-another-great-judgment-on-private-enforcementfrom-the-cjeu-but-it-could-be-better/.

${ }^{29}$ See paragraph 143 of the AG Opinion.
} 
ULP Law Review | Revista de Direito da ULP

Vol. 13, n. .1

doi:10.46294/ulplr13nlv1

Despite the undeniable relevance of this ruling for the private enforcement of competition law, it should be noted that the ECJ does not clarify which elements have to be fulfilled, in the concrete case, in order to be established a "causal relationship ${ }^{\prime \prime 30}$. The reluctance of the ECJ to go deeper, albeit in an abstract way, in the requirements for compensation allows the EU competition law to be applied, in a disparate manner, by MS.

${ }^{30}$ See DAVID VAN WAMEL, Otis II: A Lost Opportunity to Clear the Mist, Lexxion Competition Blogs, 2020, https://www.lexxion.eu/en/coreblogpost/otis-ii-a-lost-opportunity-to-clear-the-mist/. 